\title{
Introducing extracorporeal membrane oxygenation (ECMO) for healthcare professionals: the importance of a basic theoretical course
}

\author{
G Liguori*, J Penha, L Miana, L Caneo, C Tanamati, M Jatene \\ From 23rd World Congress of the World Society of Cardio-Thoracic Surgeons \\ Split, Croatia. 12-15 September 2013
}

\begin{abstract}
Introduction
A multidisciplinary team is essential for a high quality ECMO service. However, few health professionals have any knowledge on ECMO and, in addition, there are discrepancies between the level of expertise among these professionals. Thus, we evaluated the impact of a basic theoretical ECMO course on the knowledge gain of different healthcare professionals.
\end{abstract}

\section{Methods}

A basic six-hour theoretical course on ECMO was taught to a heterogeneous audience formed by 12 medical students, 10 nurses, 4 perfusionists and 4 physicians. Content included the following topics: 1) concept of ECMO; 2) usage scenarios; 3 ) aspects of the circuit; 4) differences between pulmonary and cardiac ECMO; 5) management of patients on ECMO; 6) aspects of cannulation; 7) complications; 8) concept of E-CPR; and 9) importance of the multidisciplinary team. Questionnaires for self-evaluation, graduating from 1 to 5 the level of expertise on the referred topics, were conducted immediately before and after the course.

\section{Results}

Twenty-six $(76,6 \%)$ questionnaires were completed. The three most clear topics before the course were the importance of the multidisciplinary team $(2,96 \pm 1,36)$, the concept of ECMO $(2,57 \pm 1,27)$ and usage scenarios $(2,39 \pm 1,2)$, while the three less clear were the concept of E-CPR $(1,65 \pm 0,93)$, management of patients on ECMO $(1,87 \pm 1,01)$ and aspects of cannulation $(1,91 \pm 1,12)$. An important, although not significant, discrepancy between

\footnotetext{
*Correspondence: gabrielliguori@gmail.com

Heart Institute (InCor), University of Sao Paulo Medical School, Sao Paulo,
} Brazil

C 2013 Liguori et al; licensee BioMed Central Ltd. This is an Open Access article distributed under the terms of the Creative Commons Attribution License (http://creativecommons.org/licenses/by/2.0), which permits unrestricted use, distribution, and reproduction in any medium, provided the original work is properly cited.
doi:10.1186/1749-8090-8-S1-P52
Cite this article as: Liguori et al:: Introducing extracorporeal membrane oxygenation (ECMO) for healthcare professionals: the importance of a basic theoretical course. Journal of Cardiothoracic Surgery 2013 8(Suppl 1): P52.

Submit your next manuscript to BioMed Central and take full advantage of:

- Convenient online submission

- Thorough peer review

- No space constraints or color figure charges

- Immediate publication on acceptance

- Inclusion in PubMed, CAS, Scopus and Google Scholar

- Research which is freely available for redistribution

Submit your manuscript at www.biomedcentral.com/submit
C Biomed Central 